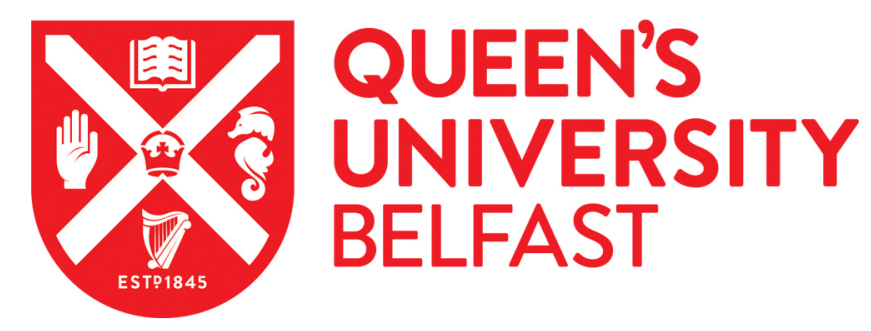

\title{
The Dynamics of Quadropoly: League Position in English Football between 1888 and 2010
}

Penn, R., \& Berridge, D. (2016). The Dynamics of Quadropoly: League Position in English Football between 1888 and 2010. The International Journal of the History of Sport, 33(3), 325-340.

https://doi.org/10.1080/09523367.2016.1175439

\section{Published in:}

The International Journal of the History of Sport

Document Version:

Peer reviewed version

Queen's University Belfast - Research Portal:

Link to publication record in Queen's University Belfast Research Portal

Publisher rights

Copyright 2016 Taylor and Francis

This is an Accepted Manuscript of an article published by Taylor \& Francis in The International Journal of the History of Sport on 04 May 2016, available online: http://www.tandfonline.com/10.1080/09523367.2016.1175439

\section{General rights}

Copyright for the publications made accessible via the Queen's University Belfast Research Portal is retained by the author(s) and / or other copyright owners and it is a condition of accessing these publications that users recognise and abide by the legal requirements associated with these rights.

Take down policy

The Research Portal is Queen's institutional repository that provides access to Queen's research output. Every effort has been made to ensure that content in the Research Portal does not infringe any person's rights, or applicable UK laws. If you discover content in the Research Portal that you believe breaches copyright or violates any law, please contact openaccess@qub.ac.uk. 
The Dynamics of Quadropoly: League Position in English Football between 1888 and 2010

Roger Penn \& Damon Berridge 
Abstract: The paper explores competitive balance in top tier English league football from its inception in 1888. It examines the extent to which finishing in the top four positions in successive seasons is the preserve of a small number of clubs. Using a range of statistical measures, the analysis shows that the current high levels of competitive imbalance are not new phenomena. The overall pattern approximates a ' $U$ curve': current patterns parallel those in the 1890s. In the early years of English league football, differences in resources between clubs soon became apparent. Clubs from the larger conurbations generated consistently larger revenues than their counterparts in the smaller industrial towns. This was primarily the result of the larger crowds that they could attract to their home games. This enabled them to entice the best players to their clubs away from their smaller rivals. The introduction of the maximum wage in 1901 and the transfer system helped to stem these increasing inequalities between clubs. This coincided with a massive wave of new stadia construction which enabled all the clubs to compete on an increasingly level playing field. These conjunctural changes to English football before 1915 produced the era of relatively competitive football during the inter-war years. This continued until the abolition of the maximum wage in 1961. Since that time, competitive balance has reversed and become increasingly restricted. English top-tier football has re-entered an era of extreme competitive imbalance.

Key Words: competitive balance, English football (soccer), statistical measures of concentration, the 'longue durée', conjunctural 
There has been growing disquiet amongst football commentators and from within the contemporary football industry over the last decade about the decreasing competitiveness of top tier (Premier League) English football ${ }^{1}$. Dave Whelan, owner of Wigan Athletic, made his views clear in a typically forthright interview with the Sunday Express ${ }^{2}$ : 'we know that next year one of the top four teams will win the league and the other three will be in the top four again. That is not competitive'. He also pointed out forcefully that the 'Big Four' quadropoly was sustained by their enormous revenues earned in the Champions' League.

There has also been considerable debate in the social scientific literature about the nature of competitive balance in football and within sport in general. Competitive balance refers to balance between the sporting capabilities of football teams. The more evenly matched the competitive strengths of the teams, the more uncertain the outcome of each game. Similarly, the more evenly balanced the teams, the more uncertain the outcome of the title race. A wide range of measurement tools have been utilized by a variety of authors designed to capture the degree of competitive balance and imbalance. Each of the measures used has strengths and weaknesses which revolve around the attempt to encapsulate a complex phenomenon within one summary measure. In the end there is no 'Holy Grail' in the field of summary measures: there is no one measure that is either the correct or even the most appropriate measure in every circumstance. Each summary measure focuses on a different feature of the problem. In this paper we utilize three different measures of competitive balance that are designed to tease out different aspects of the phenomena.

Most empirical analyses of competitive balance in English football have used relatively short term time frames. Szymanski ${ }^{3}$ examined competitive balance in English top tier football between 1976 and 1998. Fedderson and Maennig ${ }^{4}$ looked at the period between 1969 and 2004, whilst Goossens ${ }^{5}$ focussed on a slightly longer period between 1963 and 2005. Curran et $a l^{6}$ looked at a longer set of data about the English top tier from the year 1948 up to 2008. Dobson and Goddard ${ }^{7}$ also suggested that competitive balance remained 'roughly unchanged between 1947 and the 1980s, and had risen thereafter'. Naghshbandi et $a l^{8}$ conversely only examined one season (2009-2010) in their comparison of six countries 
and Scelles et $a l^{9}$ limited their own comparative research to the period between 2008 and 2011.

The empirical results of these analyses are mixed. Most agree that there has been an increase in competitive imbalance in recent years in English top tier football but, as we have seen, the historical benchmarks used are varied. Szymanski ${ }^{10}$ argued that competitive balance was 'relatively stable' but Goossens concluded that 'England displays a very moderate linear rise in imbalance'11. Subsequently Curran et al argued that 'all the data ...suggest that competitive balance is decreasing in the top level of English football ${ }^{\prime 12}$. This was attributed to the twin forces of the Premier League and the UEFA Champions' League. More recently Dousti et al suggested that 'since the English Premier League broke away from the Football League in 1992, the EPL has virtually lost its competitive balance ${ }^{13}$. The present paper is designed to explore the contours of competitive balance in the current period and to assess the extent to which these patterns are new. In particular, the evidence provided in this analysis takes a long-term perspective and examines competitive balance during the period between 1888 and 2010 .

\section{Structural continuity and conjunctural change}

The analysis presented in this paper was underpinned by a set of theoretical and conceptual points of departure. These suggested that social change is both an empirical process and that it often occurs over relatively long periods of time. It was influenced by the templates set out by the Annales School ${ }^{14}$ of structural history. In this approach, a distinction is made between 'events', which comprise immediate phenomena of interest for traditional forms of historical analysis, and both 'structures' and 'conjunctures'. 'Structures' represent longstanding features of societies that often exist for lengthy periods of over a century in duration. 'Conjunctures' are shorter periods of time and correspond closely to 'eras' in everyday discourse: they are periods of relative stability in social forms but are set within deeper longer-term sedimented structures (the 'longue durée' in the terminology of the Annales School). Both structures and conjunctures are distinct from the immediate daily flux of events and point to much longer periods of continuity and change. 
Based upon this model, we have taken the years from 1888 to 2010 as one 'structural' entity: the period of professional competitive league football in England. During this period of over a century in duration, English football clubs were organized as privately-owned capitalist enterprises $^{15}$ with a small number of large shareholders who, as directors, controlled their finances. This social class basis to the ownership of professional football in England was reinforced physically within the internal spatial organization of the stadia themselves, where separate areas of seating and facilities within the stands catered for the owners' match-day needs. Our analysis explores the extent to which there have been significant changes in competitive balance between top-tier clubs in England during this period. We also examine subdivisions within this overall 'longue durée' of English top tier league football. These comprise either decades - which were used for heuristic purposes or conjunctures which represent significant discontinuities within the overall trajectory of football historically. This style of analysis has been used recently by Penn ${ }^{16}$ to explore the national origins of footballers, managers and owners in English and Italian football between 1930 and 2010.

As has been shown, there has been considerable debate amongst pundits, journalists and academics in recent years over the increasing tendency that the top four positions in the Premier League are taken by the same teams year after year. This is of considerable importance for the competitive performance of such clubs, as finishing in one of the top four positions currently guarantees entry into the lucrative Champions' League. However, is this really the case? Few of the protagonists provide systematic data on changing finishing positions in the top tier of English football over the 'longue durée'. None has provided evidence from earlier than 1945. Historians of competitive balance prior to $1914^{17}$ have shown it to have been a period when a relatively small number of clubs dominated. However, there is a disjunction in the existing literature. No previous research has examined finishing positions in the top tier of English football since its inception in 1888 through to the contemporary era. In order to achieve this, the finishing positions of all teams in the top tier since 1888 were entered into Excel along with their total number of points. In this paper we will initially explore and analyze finishing position by comparing the number of different clubs who have finished in the top four positions in the top tier since 1888 over a succession 
of decades using descriptive statistics. The data are presented initially in three tables: the first examines the period from 1888 until 1915, the second examines the decades from the 1920 s up to the end of the 1950s and the final table examines the period from 1960 up to 2010. As part of the analysis, we explored these patterns using overlapping decades (i.e. 1895-1904, 1905-1914, etc.). The results were virtually identical, thereby supporting the robustness of the analysis presented below.

\section{Conjuncture 1: 1888-1915 - the classic era}

The first conjuncture covers the period from the inception of organized competitive English professional league football in 1888 until the cessation of football in 1915 as a result of the increasing severity of the First World War. In this era, professional league football was concentrated in the industrial heartlands of English manufacturing industry in the North and the Midlands. During this period the game gained enormously in popularity and the classic, iconic stadia were built to accommodate burgeoning crowds. Previous analysts like Mason and Vamplew ${ }^{18}$ and, to a lesser extent, Taylor ${ }^{19}$ have categorized this conjuncture as the 'classic' period of English league football.

It is clear from Table 1a that certain clubs were dominant in this era. Preston North End, Blackburn Rovers and Wolverhampton Wanderers finished in the top four positions in both the $1888-1889$ and $1889-1890$ seasons. Moreover, the 1890 s witnessed the dominance of three teams in the top four places in the First Division of the English league. These were Aston Villa, Everton and Sunderland. This was the result of a range of factors, most notably the differences in resources between English league clubs at this time. Preston famously lost the key members of its 'Invincibles' team in 1890 to clubs with much stronger finances, including Everton and Sunderland ${ }^{20}$. These same three clubs along with Newcastle United the team of the first decade of the twentieth century ${ }^{21}$ - dominated the league during the first decade of the twentieth century. Nonetheless, 15 different clubs featured in the top four during the 1900s. All but Bristol City were from the original Northern and Midlands heartlands of the league at that time.

\section{TABLE 1a ABOUT HERE}


In the decade from 1910 to 1919 (six seasons in total - the result of the suspension of league football after 1915 due to the Great War), 14 clubs featured in the top four of the First Division. Only Chelsea from the South achieved this feat. None of the Yorkshire teams that were so successful in the FA Cup during these years achieved a top four finish. Indeed, only Sheffield Wednesday from outside Lancashire, the North East and the Midlands were top-four finishers.

\section{Conjuncture 2: 1920-1960 - the golden age}

The second conjuncture covers the period between the resumption of league competition after the First World War until the abolition of the maximum wage in 1961. This was the heyday of English self-imagined footballing hegemony. English clubs maintained their traditional restrictions on payments for players and upon the free movement of these same players. Crowds increased further, reaching their apotheosis just after the Second World War. However, changes were evident towards the end of this era with the advent of both European competitions and flood-lit matches ${ }^{22}$.

The 1920s witnessed a pattern similar to earlier decades. Huddersfield Town were the most successful club in this decade with six top-tier finishes which included a hat-trick of First Division titles. Sunderland, Bolton Wanderers and Liverpool were the other dominant clubs. Seventeen different clubs finished in the top four during the decade, with Cardiff City, Arsenal and Leicester City widening the geographic spread of top four finishers. Nonetheless, only three top-four finishers were from outside the traditional core of English league football in the North and the Midlands. This pattern changed somewhat in the 1930s which was the decade of Arsenal's persistent success with seven top-four finishes. Sixteen clubs featured in the top four during this decade, including Sheffield Wednesday (four appearances), Charlton Athletic (three), Derby County (three) and Huddersfield Town (three).

\section{TABLE 1b ABOUT HERE}

The 1940s were truncated by the suspension of traditional league football for the duration of the Second World War. Manchester United, under their new manager Matt Busby, finished in the top four during every season between 1946 and 1950. Portsmouth, 
Wolverhampton Wanderers and Derby County managed two top four finishes during these four post-war seasons. The 1950s witnessed the continued dominance of Wolverhampton Wanderers (seven appearances in the top four) and Manchester United (six), as well as success by Tottenham Hotspur (five) and West Bromwich Albion (four).

\section{Conjuncture 3: $1960-2010$ - postmodern football}

The final conjuncture covers the period from the abolition of the maximum wage to the present. It has been characterized as an era of emerging post-modernism within football ${ }^{23}$. The traditional features of the game have been progressively dismantled in an era of increasing globalization. This has been associated with an ever-growing impact of television on the game, particularly satellite pay-to-view programming. Games no longer involve the ritual of a 3pm kick-off on a Saturday. Matches now take place over a wide range of differing starting times which are dictated largely by satellite television and the scheduling of various European-wide competitions ${ }^{24}$. The game has ceased to be primarily working class in terms of spectators ${ }^{25}$. The price of tickets has grown enormously in the current conjuncture ${ }^{26}$, partly as a consequence of the imposition of all-seater stadia ${ }^{27}$ after the Taylor Report ${ }^{28}$ into the Hillsborough disaster.

These developments have paralleled a simultaneous branding of clubs and supporters. The incorporation of supporters into clubs' brands is more than simply economic. Contemporary Premier League football stadia have been radically transformed into multifunctional sites where playing football is one activity amongst many ${ }^{29}$. Indeed they provide venues for major rites of passage, including weddings, baptisms, funerals and barmitzvahs ${ }^{30}$. These matters of 'life and death' involve the symbolic and emotional bonding of clubs with their supporters which transcends the purely material.

The 1960s witnessed the continued dominance of Manchester United and Tottenham Hotspur as well as the successes of Everton and Leeds United, neither of whom had featured in the top four since before the Second World War. The 1970s witnessed the dominance of Liverpool and, to a lesser extent, Ipswich Town, Derby County and Leeds United. Liverpool remained dominant during the 1980s, along with Manchester United, Tottenham and Arsenal. However, the number of different clubs in top-four positions 
continued to decline from 15 in the 1950s and 1960s to 13 by the 1980 s. This secular decline continued into the 1990s when Manchester United, Arsenal and Liverpool continued to dominate top four finishes. The decade from 2000 to 2010 witnessed the smallest number of top-four-finishing teams since the inception of the league in 1888 . Only eight clubs finished in the top four during that decade. Arsenal and Manchester United occupied one of the top four slots in every season during the decade and Chelsea managed it eight times out of ten. Liverpool was successful in seven seasons. Of the other four teams finishing in the top-four positions, only Newcastle United finished in the top four for more than one season.

\section{TABLE 1c ABOUT HERE}

\section{Measures of concentration}

In this paper we present three measures of concentration in English top tier football since 1888. The first involves a single index of concentration which measures the degree to which the same four teams occupy the top four positions over a given decade. The minimum number of clubs finishing in the top four over a decade would be four: in other words the same clubs occupy the top four positions in the league in all 10 seasons. Our index in this situation would take a value of one. The maximum number of clubs that could finish in the top-four positions over 10 seasons would be 40: in this case no club finished in the top-four finishing positions more than once in 10 seasons. Our index would take a value of zero in this situation.

\section{FIGURE 1 ABOUT HERE}

It is evident from Figure 1 that the concentration index has changed over time. The values for the index of concentration are presented in the last row of Tables $1 \mathrm{a}, 1 \mathrm{~b}$ and $1 \mathrm{c}$. In the simplest terms the overall shape approximates a U-curve. It is also clear that the level of concentration increased sharply from the 1990 s to the 2000 s. We shall return to this later in the analysis.

Why was there a relatively high level of concentration in the old First Division in its early years and why did it fall towards the beginning of the First World War? There was a series of inter-related factors at work. The first involved the large differences in revenues between 
clubs that emerged very soon after the inception of the Football League in $1888^{31}$. Preston North End - who won the first two championships ${ }^{32}$ - found it increasingly difficult to compete with teams from the larger conurbations like Everton, Aston Villa and Sunderland ${ }^{33}$. The same applied to Bolton Wanderers ${ }^{34}$, Blackburn Rovers ${ }^{35}$, Burnley ${ }^{36}$ and Accrington. These clubs from the medium-sized Lancashire mill towns could only attract large gates intermittently. These generally featured games against either their nearest rivals geographically or one of the leading teams in the First Division at the time of the match ${ }^{37}$ or at Christmas and the New Year. The bulk of revenues at this time came from gate receipts ${ }^{38}$, although Preston infamously received illegal financial support via their General Manager, Major Sudell, who was imprisoned for embezzlement in 1895.

A major factor exacerbating these economic differences between England's top tier clubs was the creation of the transfer system in 1893. This enabled the economically more powerful clubs to buy players from their smaller rivals. However, it was even more effective in funding the continued flow of professional players from Scotland. There had been a longstanding connection between the top English clubs and Scotland dating back to the early $1880 \mathrm{~s}^{39}$. Blackburn Rovers, Darwen and Preston North End employed large numbers of Scottish players as professionals at this time ${ }^{40}$. By 1910, 23.5\% of English First Division players were Scots ${ }^{41}$. Clubs like Newcastle United ${ }^{42}$, Sunderland, Liverpool and Everton continued to recruit large numbers of Scots both before and after the First World War ${ }^{43}$.

This migratory pattern reflected the strength of Scottish football in the period before 1914. Scotland was the home of tactical innovation in the last quarter of the nineteenth century ${ }^{44}$. The Scottish 'passing game' proved superior to the more traditional 'dribbling' style prevalent amongst the earliest English teams. Indeed, between 1872 and 1887, Scotland won ten of the annual international fixtures with England. England only secured two victories during the same period. The transfer system enabled the more affluent clubs to outbid their smaller rivals in the market for Scottish imports.

The dominance of the larger financially powerful clubs led to a counter reaction. In 1901, after almost a decade of attempts, the Football League brought in a maximum wage for all players in an attempt to level the competitive field between clubs. In many ways this was successful. T. Sydney - a director of Wolverhampton Wanderers - argued that competitive 
balance was the result of the imposition of the maximum wage which 'had worked well because clubs were of a much more equal playing strength'45. The dominance of the traditional large clubs like Aston Villa, Everton and Sunderland was somewhat curtailed. Between 1900 and 1915 significantly more teams finished in the top four (see Table 1a) and the index of concentration fell to its lowest level in the entire period between 1888 and 2010 (see Figure 1). Vamplew, in his seminal economic history of British sport prior to the First World War, also provided strong corroborative evidence that there was increasing competitive balance in the English First Division in the first two decades of the twentieth century prior to 1915 (see his Tables 9.12 and 9.13) ${ }^{46}$.

A significant factor in this process of equalization was the increasing popularity of football itself. Most clubs developed large stadia during the period between 1900 and 1910. Taylor ${ }^{47}$ reported that ' 58 leading professional clubs in England... moved to new grounds between 1889 and 1910'. Korr ${ }^{48}$ outlined in detail West Ham United's huge investment in their new Boleyn Ground between 1911 and 1913. Indeed most profits earned by First Division clubs were used to finance ground improvements at this time ${ }^{49}$. This enabled the teams from smaller localities to compete financially on a more even footing with the clubs from the larger conurbations as they were able to match their revenues from gate receipts as a result of the equalization of attendances in the top tier (see Figure 2). Blackburn Rovers, for instance, opened their new stadium at Ewood Park in $1907^{50}$ and used the revenues from the increased attendances at their First Division home fixtures to break the British transfer record three times between 1911 and $1914^{51}$. This expenditure resulted in two First Division titles in 1912 and 1914.

\section{FIGURE 2 ABOUT HERE}

The system did not work perfectly. Sunderland were fined $£ 250$ for paying their players bonuses in various forms in 1904 and three directors of the club were suspended for three years. The most dramatic case involved Manchester City who were also fined $£ 250$ in $1904^{52}$. Three years later seventeen Manchester City players were forced to resign and fined up to $£ 100$ each, partly because of being party to illegal extra payments ${ }^{53}$. They were also forbidden from playing for Manchester City again in the future ${ }^{54}$. 
Nonetheless the first half of the twentieth century witnessed a much wider spread of different clubs finishing in the top-four positions. The 1920 s saw the largest number of clubs (17) finishing in top-four positions over the entire period. Everton, for example, won the First Division title in 1928. However, they did not feature in the top four during the other years of the decade and even managed to be relegated in 1930, despite the presence of their legendary striker, Dixie Dean, who had scored 60 league goals in the year when they had won the Championship!

The 1940s was another period of low concentration. In the four seasons after the recommencement of competitive league football after the end of the Second World War, ten different clubs featured in the top-four positions in the First Division.

The top tier remained fairly competitive in the 1950 s and 1960 s but the effects of the abolition of the maximum wage in 1961 and the subsequent dramatic rise in transfer fees heralded renewed higher levels of concentration. This trend has continued to the present day. In the decade after the 2000-2001 season, the index of concentration rose to 0.89 . Two clubs - Manchester United and Arsenal - finished in the top four in every year during the decade. This was the first time that this had happened in any given decade. Chelsea and Liverpool were also frequent top-four finishers and only eight different clubs featured in the top four during the 2000s. Overall, the index of concentration increased gradually between 1960 and 2000. After 2000 there was a sharp acceleration in the level of concentration.

Our second measure involves concentration profiles over time. This extends the earlier index of concentration to measure the degree of domination amongst the top four teams in the same decade. Concentration profiles are more complex measures than the earlier concentration index and initially measure the number of seasons that the first ranked club in a decade featured in the top-four positions over that decade. This is repeated for the number of seasons that the top two ranked clubs in the decade featured in the top four over the decade and then for the top three ranked clubs and the top four ranked clubs in the decade. The curves presented in Figures $3 a, 3 b$ and $3 c$ that display these concentration profiles are therefore cumulative in nature. 
The measure can be illustrated for the 1880s (see Figure 3a). In this case there were only two seasons calibrated. The top ranked club (Blackburn Rovers) featured in both seasons and therefore scored one. The two highest ranked clubs (Blackburn Rovers and Preston North End) both featured in both seasons and the cumulative profile also scored one. Indeed, the three highest ranked clubs (Blackburn Rovers, Preston North End and Wolverhampton Wanderers) all featured in both seasons and the cumulative profile remained at one. The fourth ranked club (Aston Villa) only featured once and the four highest ranked clubs (Blackburn, Preston, Wolverhampton Wanderers and Aston Villa) therefore featured in seven of the eight possible top four finishes and the cumulative profile for these top four ranked clubs fell to 0.88 .

\section{FIGURE 3a ABOUT HERE}

In the 1890s the highest ranked club (Aston Villa) featured in eight top four finishes. This is represented on Figure $3 a$ as 0.8 . The first and second ranked clubs (Aston Villa and Everton) featured cumulatively in 14 top four finishes out of a possible 20 . This produced a concentration profile of 0.7 .

Figure 3a revealed a decline in concentration profiles during the period between 1880 and 1915. The highest concentration profile was in the 1880s and the lowest in the 1910s. Indeed, this decline in concentration profiles is monotonic. Each successive decade has a lower concentration profile than the previous decade during this era. The concentration profiles for the 1890s and 1900s also have the same shape: the vertical distance between them remains the same. In contrast, the concentration profile for the 1910 s starts at a lower level (0.5) and remains at or just below that level throughout. The 1910s display the lowest concentration profile over the entire period (although there were only six seasons included as professional football ceased after 1915 as a result of World War One).

The pattern between 1920 and 1960 (see Figure 3b) was more complex than in earlier decades. The 1920s revealed the second lowest concentration profile during the entire period under scrutiny. The highest ranked club (Huddersfield Town) featured six times in the top four, whilst the four highest ranked clubs (Huddersfield Town, Sunderland, Bolton Wanderers and Liverpool) featured in only 19 out of the 40 top four finishes. The 
concentration profile for the 1950 s is similar in shape to that for the 1920s. However, the shape of the curves representing concentration profiles in the 1930s and 1940s differed markedly from those in the 1920 s and the 1950s. The higher initial points in both the $1930 \mathrm{~s}$ and 1940s were a function of the specific dominance of Arsenal in the former and Manchester United in the latter decade.

\section{FIGURE 3b ABOUT HERE}

Overall, we can see that the concentration profiles are generally lower in the decades after 1920 than previously. This parallels the earlier findings based upon the single index of concentration. Certain clubs have always dominated the top tier of English football in any given era but their overall dominance fell between the 1890s and the 1950s. The most open decade was the 1910s. This was closely followed by the 1920 s.

The top tier of English football since 1960 has become more concentrated. In the 2000s the top two ranked clubs (Arsenal and Manchester United) both featured in the top four in every season. This is shown clearly in the concentration profile in Figure $3 c$ and mirrors the pattern for the 1880s. English top tier football in the 1960s was much more diffuse. The two highest ranked clubs (Everton and Leeds United) were each in the top four in six seasons (12 in total), whilst the third and fourth ranked clubs (Tottenham Hotspur and Manchester United) both featured five times.

\section{FIGURE 3C ABOUT HERE}

The concentration profiles for these recent decades are ordered monotonically but in the opposite direction to those from the earliest era between 1888 and 1920 . The top tier of English football became successively more concentrated in each decade after 1960 . These results are consistent with the U-curve shown in Figure 1.

The final measure of competitive balance involved calibrating coefficients of variation. These measure the degree to which teams are concentrated closely around the average (arithmetic mean) number of points scored in any given season.

These patterns can be conceptualized in terms of the degree of elongation or compression of points accrued by teams in a season. A smaller coefficient of variation indicates a 
relatively high degree of compression - most teams accrue relatively similar numbers of points. This indicates a relatively high degree of competitive balance. A larger coefficient, on the other hand, indicates a relatively high degree of elongation - teams at the top and the bottom of the league are further apart than those in a season with a small coefficient. A large coefficient of variation is another indicator of a relatively high degree of competitive balance.

The coefficients of variation plotted by season in Figure 4 reveal a U-shaped curve. Each season is represented by a point (in red) on the scatterplot. These are linked by a thin continuous line. The continuous thick blue curve embodies a smoothed estimate of the overall trend over time. The high levels of concentration at the top and bottom of the league table seen in the early years of English football (indicated by a coefficient of variation of 0.36 in 1888-1889) have only recently returned in the last decade or so (for example, coefficients of variation of 0.38 in 2007-2008 and 0.37 in 2009-2010). In the intervening period, levels of concentration at the top and bottom of the league table reached an alltime low with a coefficient of variation of 0.10 in 1927-1928.

FIGURE 4 ABOUT HERE

\section{Conclusions}

The three different measures that have been deployed in this analysis of the contours of top-tier league position in English football between 1888 and 2010 provide considerable support for the notion, popular amongst both pundits and social scientists, that competitive imbalance has been increasing in the English Premier League over recent years. There is strong evidence of a quadropoly in the current era. However, the analyses have also shown that this dominance of top-tier English football is not a new situation. There has always been considerable dominance of English football by a relatively small number of clubs. However, there has been a long-term historical shift in the particular clubs that have been dominant in England over time. In the era before the First World War, Aston Villa, Everton, Newcastle United and Sunderland were the dominant clubs. In the inter-war years, Huddersfield Town and Arsenal were dominant, along with Sheffield Wednesday and 
Sunderland. In the period from 1945 to 1960, Manchester United, Wolverhampton Wanderers and Tottenham Hotspur were consistently successful in the First Division. By the 1970s and 1980s, Liverpool and Manchester United dominated. In the last decade or so, Arsenal, Manchester United, Chelsea and Liverpool have repeatedly occupied the top four positions in the Premier League.

The various measures presented in this analysis have shown a consistent picture concerning the degree of concentration within the top-tier of English football between 1888 and 2010 . The overall trend closely approximates a U-curve: patterns of concentration are broadly similar at either end of the time scale, during the 1890 s and 2000 s, and dissimilar in the intervening period.

Why might this be so? There is a clear need to reconfigure explanations couched in terms of the putative effects of the Premier League, Sky Television or the UEFA Champions' League. These can only be contingent factors and there is a pressing need to develop an overall explanation in terms of those factors that have exacerbated the inbuilt tendency for dominance by a relatively small number of clubs. There are, of course, general sociological tendencies for dominance by the few as posited by elite theorists such as Michels, Pareto and Mosca ${ }^{55}$. There is also a pervasive tendency to oligopolistic outcomes in competitive capitalist markets as outlined by economists like Hilferding ${ }^{56}$. However, we can also point to the specific features of English football over the last century or so. Certain clubs have managed to dominate at specific times as a result of particular managers having been able to create winning dynasties for a succession of seasons in the fashion of Arsenal in the 1930s, Manchester United in the 1950s and 1960s, Liverpool in the 1970s and 1980s and Manchester United since the early 1990s. A successful club is critical for the recruitment of the best players in the transfer market and also in attracting the best young talent at youth level.

In the early years of English league football, differences in resources between clubs soon became apparent. Clubs from the larger conurbations generated consistently larger revenues than their counterparts in the smaller industrial towns. This was primarily the result of the larger crowds that they could attract to their home games. This enabled them to entice the best players to their clubs away from their smaller rivals. The introduction of 
the maximum wage in 1901 and the transfer system eight years earlier helped to stem these increasing inequalities between clubs. This coincided with a massive wave of new stadia construction which enabled all the clubs in the top tier to compete on an increasingly level playing field.

These conjunctural changes to English football between 1900 and 1915 produced the era of relatively competitive football during the inter-war years. This continued more or less intact until the abolition of the maximum wage in 1961. Since that time, competitive balance has reversed and become increasingly restricted. English top-tier football has re-entered an era of extreme competitive imbalance. The specific factors that have accelerated this development are varied but they all combine to exacerbate and intensify inherent inequalities in resources between clubs. This has been recognized by UEFA in terms of their Champions' League competition and it remains an open question as to whether the Financial Fair Play restrictions that they have introduced will affect that competition. It is even more uncertain as to whether it will impact upon the increasing competitive imbalance between clubs within the English Premier League.

\section{Disclosure statement}

No potential conflict of interest was reported by the authors. 


\section{Notes}

1. D. Campbell, 'The Game that Ate Itself', The Observer, 31 October 2004, 6.

2. J. Holden, 'Salary Cap the Only Way to Bridge Glory Gap', Sunday Express, 11 May $2008,112$.

3. S. Szymanski, 'Income Inequality, Competitive Balance and the attractiveness of team sports: Some Evidence and a Natural Experiment from English Soccer', Economic Journal 111 (2001): 69-84.

4. A. Fedderson, and W. Maennig. 'Trends in Competitive Balance: Is there Evidence for Growing Imbalance in Professional Sports Leagues?', Hamburg Contemporary Economic Discussions, no. 1 (2005): 1-13.

5. K. Goossens, 'Competitive Balance in European Football: Comparison by Adapting Measures', Rivista di Diritto ed Economia dello Sport 2, no. 2 (2006): 77-122.

6. J. Curran, I. Jennings, and J. Sedgwick. 'Competitive Balance in the Top Level of English Football, 1948-2008: An absent Principle and a Forgotten Ideal', International Journal of the History of Sport 26, no. 11 (2009): 1735-47.

7. S. Dobson and J. Goddard, 'The Economics of Football' (Second Edition), 47.

8. S. Naghshbandi, B. Yousefi, Z. Etemad, and M. Moradi. 'The Comparison of Competitive Balance in Football Premier Leagues of England, Germany, Spain, France, Italy and Iran: A Case Study from 2009-2010 Season', Journal of Human Sport \& Exercise 6, no. 4 (2011): 673-81.

9. N. Scelles, C. Durand, L. Bonnai, D. Goyeau, and W. Andreff. 'Competitive Balance versus Competitive Intensity: Is One of These Two Concepts More Relevant in Explaining Attendance? The Case of French Football Ligue 1 over the period 20082011', Applied Economics 45, no. 29 (2013): 4184-92.

10. Szymanski, 'Income Inequality, Competitive Balance and the attractiveness of team sports', 69-84.

11. Goossens, 'Competitive Balance in European Football', 77-122.

12. Curran, Jennings and Sedgwick, 'Competitive Balance in the Top Level of English Football', 1735-47. 
13. M. Dousti, J. Jamalsirat and M. Razaghi. 'Comparison of Competitive Balance between Iran and England's Football Premier League', International Journal of Sport Studies 2, no. 12 (2012): 593-597.

14. F. Braudel, La Mediterranée et le Monde Mediterranéen à l'Epoque de Philiippe II : 3 vols, Paris: Livre de Poche, 1949, 1; G. Duby, Le Dimanche de Bouvines, Paris: Gallimard, 1973, and J. Le Goff, The Birth of Purgatory, Aldershot: Scolar Press, 1990.

15. T. Mason, Association Football \& English Society, 1863-1915, Brighton: Harvester Press, 1980, and S. Tischler, Footballers and Businessmen: The Origins of Professional Soccer in England, New York: Holmes \& Meier, 1981.

16. R. Penn, 'Football, Nationalism and Globalization: A Comparison of English and Italian Football between 1930 and 2010', European Journal for Sport and Society 10, no. 4 (2013): 345-64.

17. W. Vamplew, Pay Up and Play the Game: Professional Sport in Britain, 1875-1914, Cambridge: University of Cambridge Press, 1988.

18. Mason, Association Football \& English Society, 1863-1915, and Vamplew, Pay Up and Play the Game: Professional Sport in Britain, 1875-1914.

19. M. Taylor, The Leaguers: The Making of Professional Football in England, 1900-1939, Liverpool: Liverpool University Press, 2005, and idem, The Association Game: A History of British Football, London: Routledge, 2008.

20. Mason, Association Football \& English Society, 1863-1915.

21. R. Hutchinson, The Toon: A Complete History of Newcastle United Football Club, Edinburgh: Mainstream Publishing, 1997.

22. R. Penn, 'Il calcio in notturna e la città. Verso una economia della notte' ['The changing time of kick-offs in modern football: towards a political economy of the night'], in E. Minardi, ed, Economia e Sociologia della Notte (Faenza: Homeless Books, 2000), 75-88.

23. R. Penn, 'The English Football Stadium as a Site of Post-Modern Consumption: Text and Image', Sociologia del Lavoro, No. 108 (2008): 141-149 and J. Paramio, B.

Buraimo and C. Campos, 'From Modern to Postmodern: the Development of Football Stadia in Europe', Sport in Society 11, no. 5 (2008): 517-34.

24. R. Penn, 'Sport e Sviluppo Locale: I'Esperienza del calcio inglese' ['Sport and Local Economic Development: The Case of English Football'] in U. Lago, A. Baroncelli and S. Szymanski, eds, Il Business de Calcio: Successi Sportivi e Rovesci Finanziari (Milano: EGEA, 2004), 131-147. 
25. J. Bale, 'The Changing Face of Football: Stadiums and Communities' in J. Garland, D. Malcolm and M. Rowe, eds, The Future of Football: Challenges for the Twenty-First Century (London: Routledge, 2000), 91-107.

26. D. Conn, 'Premier League ticket prices defy the very culture that built the game', The Guardian, 28 July 2014, 10.

27. R. Penn, 'Cathedrals of Sport: Football Stadia in Contemporary England', Soccer Review, 4 (2005): 27-40.

28. Lord Justice Taylor, The Hillsborough Stadium Disaster 15 April 1989: Inquiry by the Rt Hon Lord Justice Taylor [Final Report], London: HMSO (Cm 962), 1990.

29. R. Penn, and M. Kiddy, 'Sport and Health: the Return of the Local' in D. Jutting, B. Schulze and U. Müller, eds, Local Sport in Europe (Berlin: Waxmann, 2009), 283-89.

30. Penn, 'The English Football Stadium as a Site of Post-Modern Consumption', 141149.

31. Mason, Association Football \& English Society, 1863-1915, 5 and Vamplew, Pay Up and Play the Game, 2.

32. M. Metcalf, The Origins of the Football League: The First Season 1988/89, Stroud: Amberley Publishing, 2013.

33. Mason, Association Football \& English Society, 1863-1915, Chapter 2 and R. Sanders, Beastly Fury: The Strange Birth of British Football, London: Bantam Books, 2009, 144.

34. S. Marland, Bolton Wanderers: the Complete Record, Derby: DB Publishing, 2011.

35. M. Jackman, Blackburn Rovers: The Complete Record, Derby: Breedon Books, 2009.

36. E. Lee, and P. Whalley, The Pride and the Glory: 120 years of Burnley Football Club, Burnley: Burnley FC, 2002.

37. Jackman, Blackburn Rovers; Marland, Bolton Wanderers, and I. Ross, and G. Smailes, Everton: A Complete Record, Derby: Breedon Books, 1993.

38. Vamplew, Pay Up and Play the Game, 80-83.

39. Sanders, Beastly Fury, 111-113.

40. C. Francis, History of Blackburn Rovers F.C. 1875-1925, Blackburn: Toulmin, 1925, and Sanders, ibid.

41. Vamplew, Pay Up and Play the Game, 205.

42. Hutchinson, The Toon. 
43. P. Lanfranchi, and M. Taylor, Moving with the Ball: The Migration of Professional Footballers, Oxford: Berg, 2001, and Penn, 'Football, Nationalism and Globalization', 345-64.

44. Sanders, Beastly Fury, Chapter 4.

45. Vamplew, Pay Up and Play the Game, 136.

46. Vamplew, Pay Up and Play the Game, 134-135.

47. Taylor, The Association Game, 72.

48. C. Korr, West Ham United: The Making of a Football Club, London: Duckworth, 1986, Chapter 3.

49. Vamplew, Pay Up and Play the Game, 86.

50. C. Sutcliffe, and F. Hargreaves, History of the Lancashire Football Association, 18781928, Blackburn: Toulmin, 1928.

51. Jackman, Blackburn Rovers.

52. Sanders, Beastly Fury, 241.

53. S. Inglis, Soccer in the Dock: A History of British Football Scandals 1900 to 1965, London: Collins, 1985, Chapter 2.

54. J. Harding, Football Wizard. Derby: Breedon Books, 1985.

55. R. Michels, Political Parties: A Sociological Study of the Oligarchic Tendencies of Modern Democracy, Glencoe, III: Free Press, 1968; V. Pareto, The Rise and Fall of Elites: An Application of Theoretical Sociology, Piscataway, NJ: Transaction Books, 1991, and G. Mosca, The Ruling Class, New York: Ulan Press, 2012.

56. R. Hilferding, Finance Capital: A Study in the Latest Phase of Capitalist Development, London: Routledge, 2007. 
Table 1a: list of most successful teams in the decades between 1888 and 1915

\begin{tabular}{|c|c|c|c|c|c|c|c|c|}
\hline Decade & \multicolumn{2}{|c|}{$1880 \mathrm{~s}$} & \multicolumn{2}{|c|}{$1890 \mathrm{~s}$} & \multicolumn{2}{|c|}{$1900 \mathrm{~s}$} & \multicolumn{2}{|c|}{ 1910s } \\
\hline Number of seasons in decade & \multicolumn{2}{|c|}{2} & \multicolumn{2}{|c|}{10} & \multicolumn{2}{|l|}{10} & \multicolumn{2}{|l|}{6} \\
\hline 2nd most successful team in decade & Preston & 2 & Everton & 6 & Everton & 5 & Blackburn & 3 \\
\hline 4th & Aston Villa & 1 & Preston & 5 & Aston Villa & 4 & Burnley & 2 \\
\hline 5 th & Everton & 1 & Derby County & 3 & Man City & 3 & Man Utd & 2 \\
\hline 6th & & & Sheffield Utd & 3 & Sheffield Utd & 3 & Oldham & 2 \\
\hline$\ldots$ & & & Blackburn & 1 & Liverpool & 2 & Chelsea & 1 \\
\hline 10th & & & Burnley & 1 & Bristol City & 1 & Liverpool & 1 \\
\hline$\ldots$ & & & Liverpool & 1 & Man Utd & 1 & Middlesbrough & 1 \\
\hline$\ldots$ & & & Notts County & 1 & Nottm Forest & 1 & Newcastle & 1 \\
\hline$\ldots$ & & & & & Notts County & 1 & (Sheffield) Wed & 1 \\
\hline$\ldots$ & & & & & Preston & 1 & West Brom & 1 \\
\hline
\end{tabular}


Table 1b: list of most successful teams in the decades between 1920 and 1960

\begin{tabular}{|c|c|c|c|c|c|c|c|c|}
\hline Decade & \multicolumn{2}{|l|}{ 1920s } & \multicolumn{2}{|c|}{ 1930s } & \multicolumn{2}{|c|}{ 1940s } & \multicolumn{2}{|c|}{$1950 \mathrm{~s}$} \\
\hline Number of seasons in decade & \multicolumn{2}{|l|}{10} & \multicolumn{2}{|l|}{9} & \multicolumn{2}{|c|}{4} & \multicolumn{2}{|c|}{10} \\
\hline Most successful team in decade & Huddersfield & 6 & Arsenal & 7 & Man Utd & 4 & Wolves & 7 \\
\hline 2nd most successful team in decade & Sunderland & 5 & Sheffield Wed & 4 & Derby County & 2 & Man Utd & 6 \\
\hline $3 r d$ & Bolton & 4 & Charlton & 3 & Portsmouth & 2 & Tottenham & 5 \\
\hline 4th & Liverpool & 4 & Derby & 3 & Wolves & 2 & West Brom & 4 \\
\hline 5th & Aston Villa & 2 & Huddersfield & 3 & Arsenal & 1 & Arsenal & 3 \\
\hline 6th & Burnley & 2 & Aston Villa & 2 & Burnley & 1 & Blackpool & 3 \\
\hline 7th & Cardiff & 2 & Everton & 2 & Liverpool & 1 & Preston & 3 \\
\hline$\ldots$ & Derby County & 2 & Man City & 2 & Newcastle & 1 & Portsmouth & 2 \\
\hline$\ldots$ & Leicester & 2 & Sunderland & 2 & Stoke & 1 & Bolton & 1 \\
\hline 10th & Man City & 2 & Wolves & 2 & Sunderland & 1 & Burnley & 1 \\
\hline$\ldots$ & Newcastle & 2 & Middlesbrough & 1 & & & Chelsea & 1 \\
\hline$\ldots$ & (Sheffield) Wed & 2 & Portsmouth & 1 & & & Huddersfield & 1 \\
\hline$\ldots$ & Arsenal & 1 & Preston & 1 & & & Man City & 1 \\
\hline$\ldots$ & Bury & 1 & Stoke & 1 & & & Newcastle & 1 \\
\hline 15th & Everton & 1 & Tottenham & 1 & & & Sunderland & 1 \\
\hline$\ldots$ & Tottenham & 1 & West Brom & 1 & & & & \\
\hline 17th & West Brom & 1 & & & & & & \\
\hline Total number of teams in top four & \multicolumn{2}{|l|}{17} & \multicolumn{2}{|l|}{16} & \multicolumn{2}{|c|}{10} & \multicolumn{2}{|c|}{15} \\
\hline Concentration index & \multicolumn{2}{|l|}{0.64} & \multicolumn{2}{|l|}{0.62} & \multicolumn{2}{|c|}{0.50} & \multicolumn{2}{|c|}{0.69} \\
\hline
\end{tabular}


Table 1c: list of most successful teams in the decades between 1960 and 2010

\begin{tabular}{|c|c|c|c|c|c|c|c|c|c|c|}
\hline Decade & \multicolumn{2}{|l|}{$1960 \mathrm{~s}$} & \multicolumn{2}{|l|}{$1970 \mathrm{~s}$} & \multicolumn{2}{|l|}{$1980 \mathrm{~s}$} & \multicolumn{2}{|l|}{$1990 \mathrm{~s}$} & \multicolumn{2}{|l|}{$2000 s$} \\
\hline Number of seasons in decade & \multicolumn{2}{|l|}{10} & \multicolumn{2}{|l|}{10} & \multicolumn{2}{|l|}{10} & \multicolumn{2}{|l|}{10} & \multicolumn{2}{|l|}{10} \\
\hline Most successful team in decade & Everton & 6 & Liverpool & 9 & Liverpool & 9 & Man Utd & 9 & Arsenal & 10 \\
\hline 2nd most successful team in decade & Leeds & 6 & Ipswich & 5 & Man Utd & 6 & Arsenal & 7 & Man Utd & 10 \\
\hline $3 r d$ & Man Utd & 5 & Derby County & 4 & Tottenham & 5 & Liverpool & 6 & Chelsea & 8 \\
\hline 4th & Tottenham & 5 & Leeds & 4 & Arsenal & 4 & Leeds & 4 & Liverpool & 7 \\
\hline 5 th & Burnley & 4 & Arsenal & 3 & Everton & 4 & Blackburn & 3 & Newcastle & 2 \\
\hline 6th & Liverpool & 4 & Everton & 3 & Nottm For & 3 & Newcastle & 3 & Everton & 1 \\
\hline 7th & Chelsea & 2 & Man City & 3 & Aston Villa & 2 & Aston Villa & 2 & Leeds & 1 \\
\hline$\ldots$ & Arsenal & 1 & Man Utd & 2 & Ipswich & 2 & Chelsea & 2 & Tottenham & 1 \\
\hline$\ldots$ & Derby Cty & 1 & Nottm For & 2 & Norwich & 1 & Crystal Palace & 1 & & \\
\hline 10th & Ipswich & 1 & Aston Villa & 1 & Southampton & 1 & Norwich & 1 & & \\
\hline$\ldots$ & Leicester & 1 & QPR & 1 & Watford & 1 & Nottm For & 1 & & \\
\hline$\ldots$ & Man City & 1 & Tottenham & 1 & West Brom & 1 & Sheff Wed & 1 & & \\
\hline$\ldots$ & Nottm For & 1 & West Brom & 1 & West Ham & 1 & & & & \\
\hline$\ldots$ & Sheff Wed & 1 & Wolves & 1 & & & & & & \\
\hline 15th & Wolves & 1 & & & & & & & & \\
\hline Total number of teams in top four & 15 & & 14 & & 13 & & 12 & & 8 & \\
\hline Concentration index & 0.69 & & 0.72 & & 0.75 & & 0.78 & & 0.89 & \\
\hline
\end{tabular}




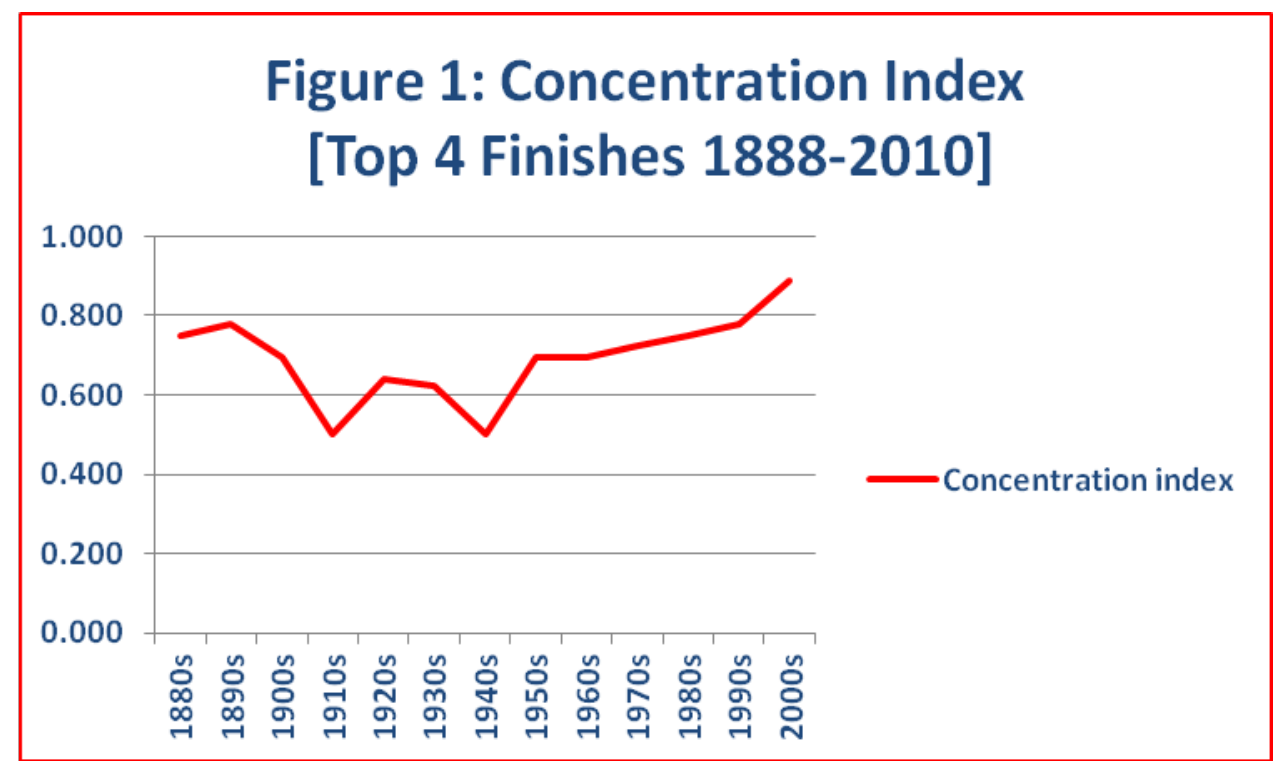

Figure 2: Average Attendances 1893/4-1913/14

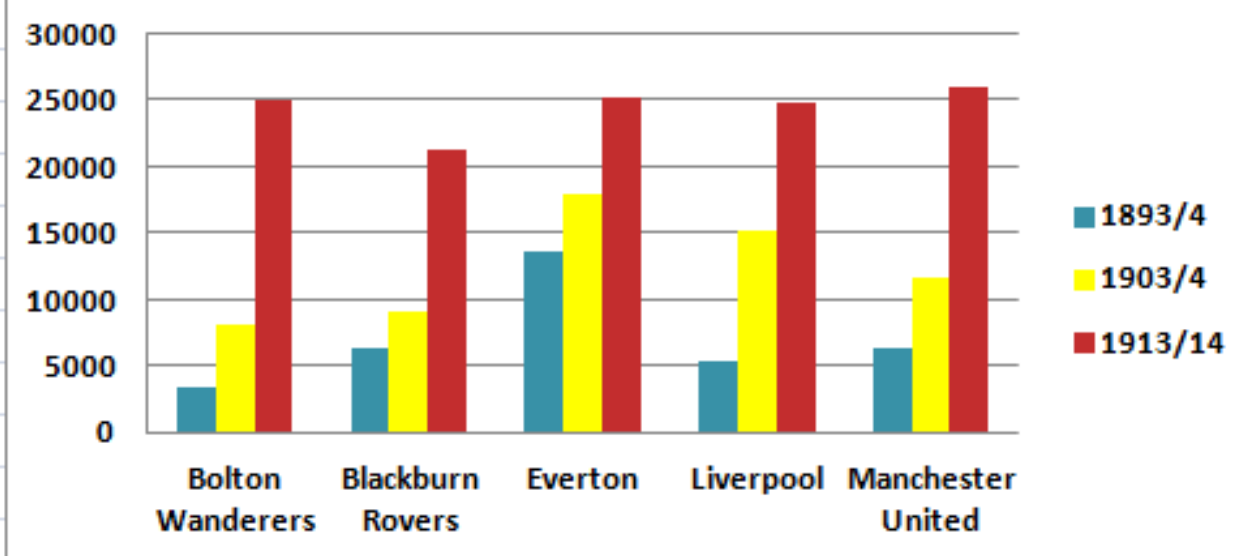


Figure 3a. Concentration Profiles, 1888 to 1915

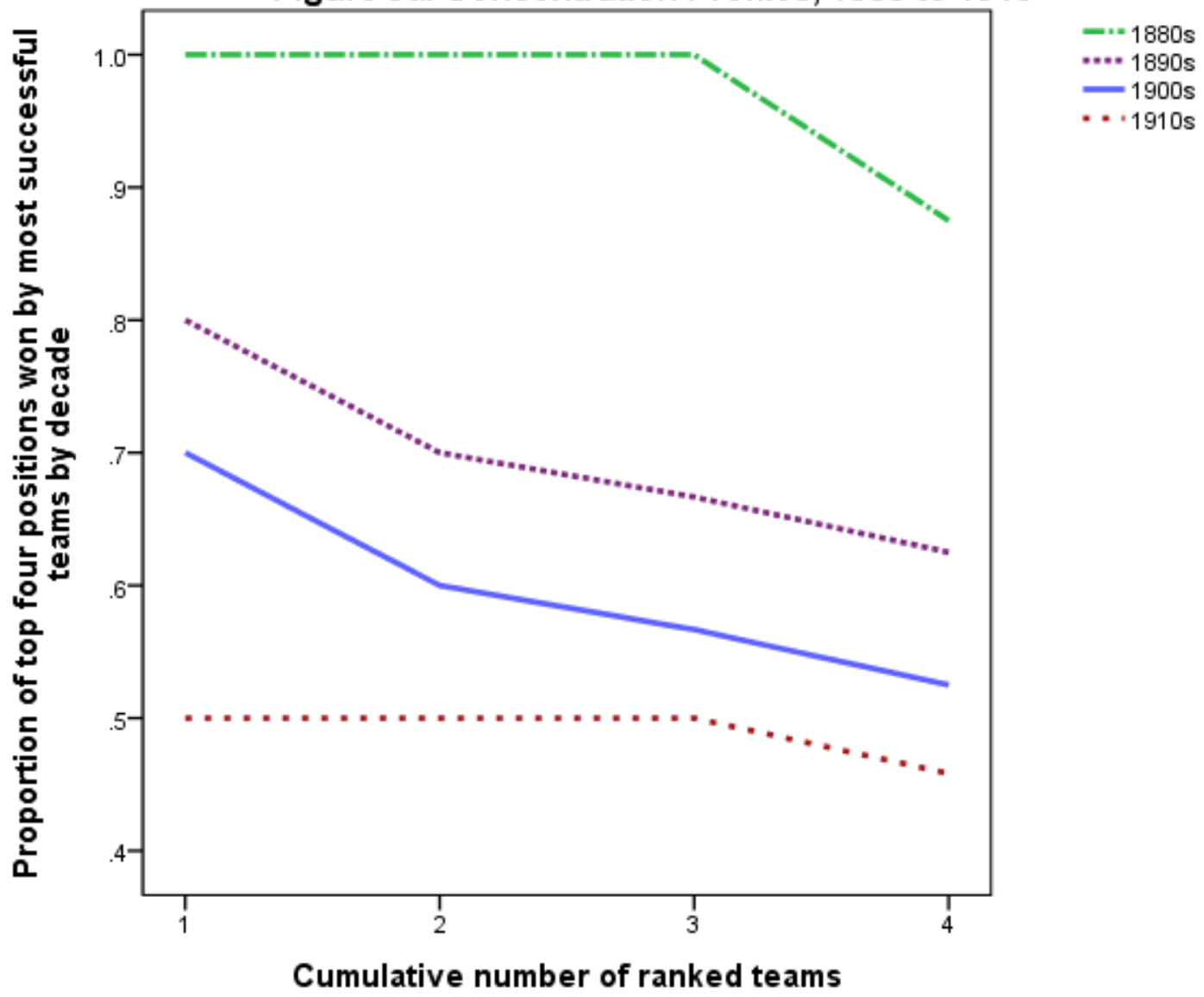


Figure 3b. Concentration Profiles, 1920 to 1960

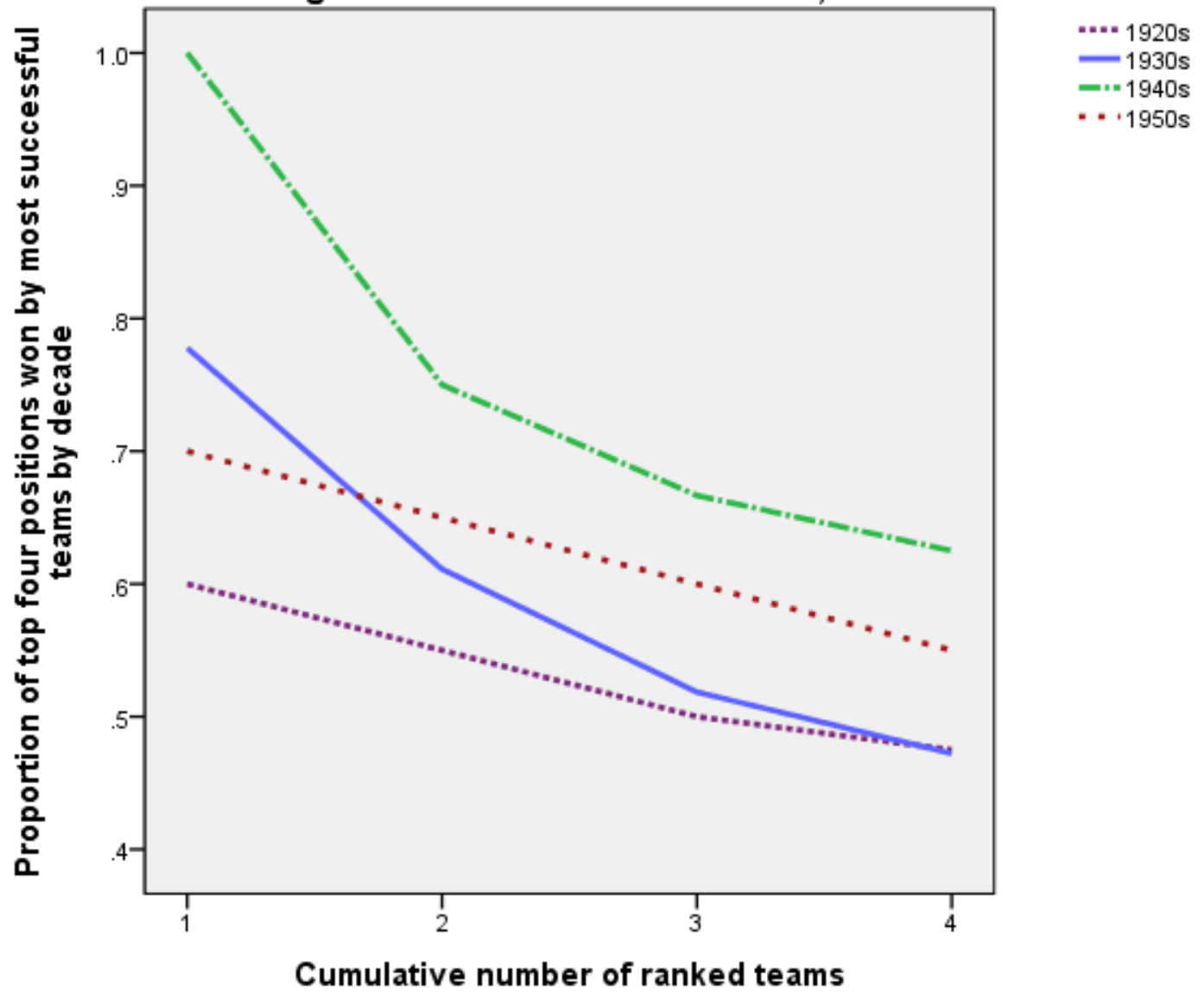


Figure 3c. Concentration Profiles, 1960 to 2010

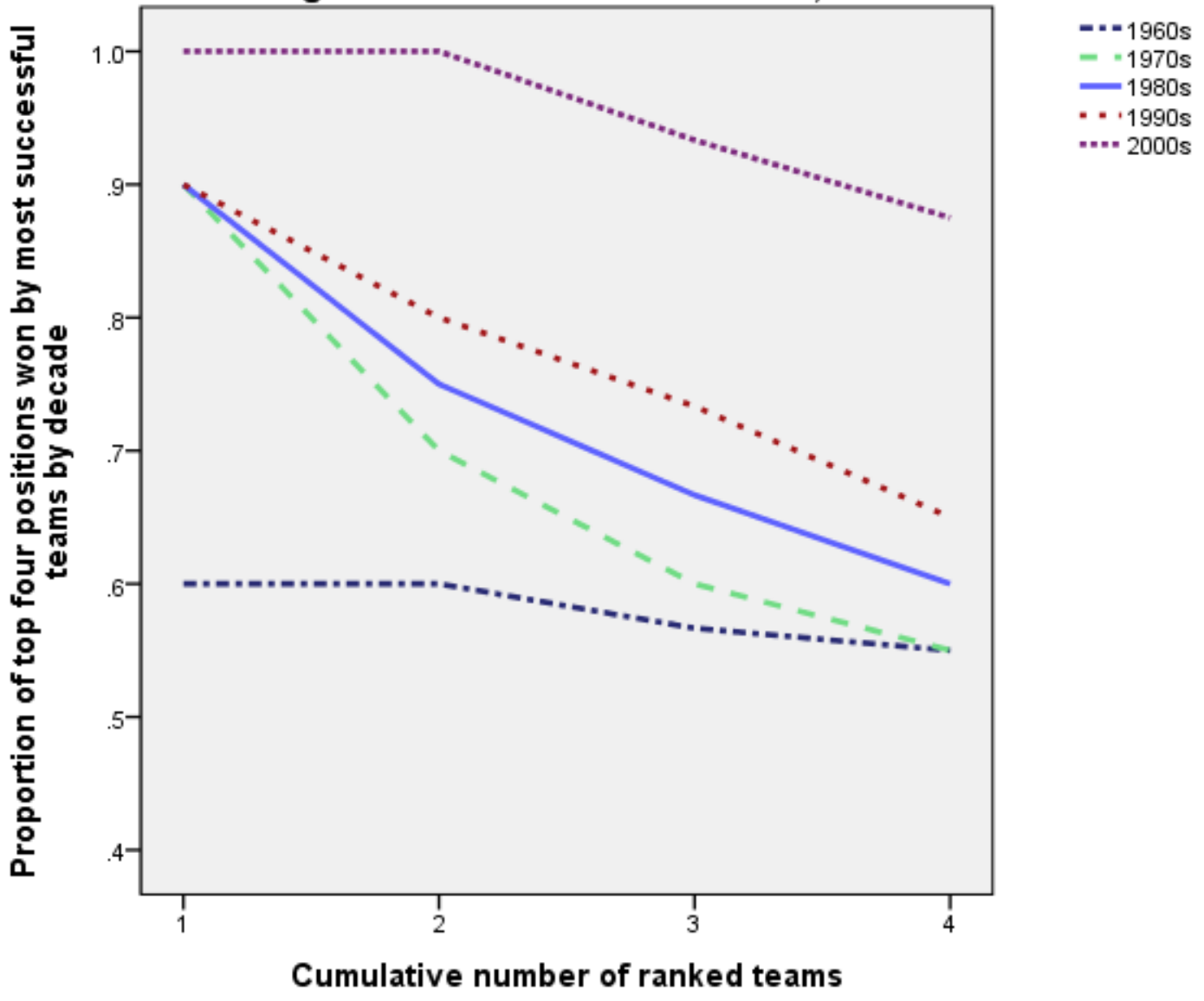


Figure 4: Coefficients of Variation, 1888-2010

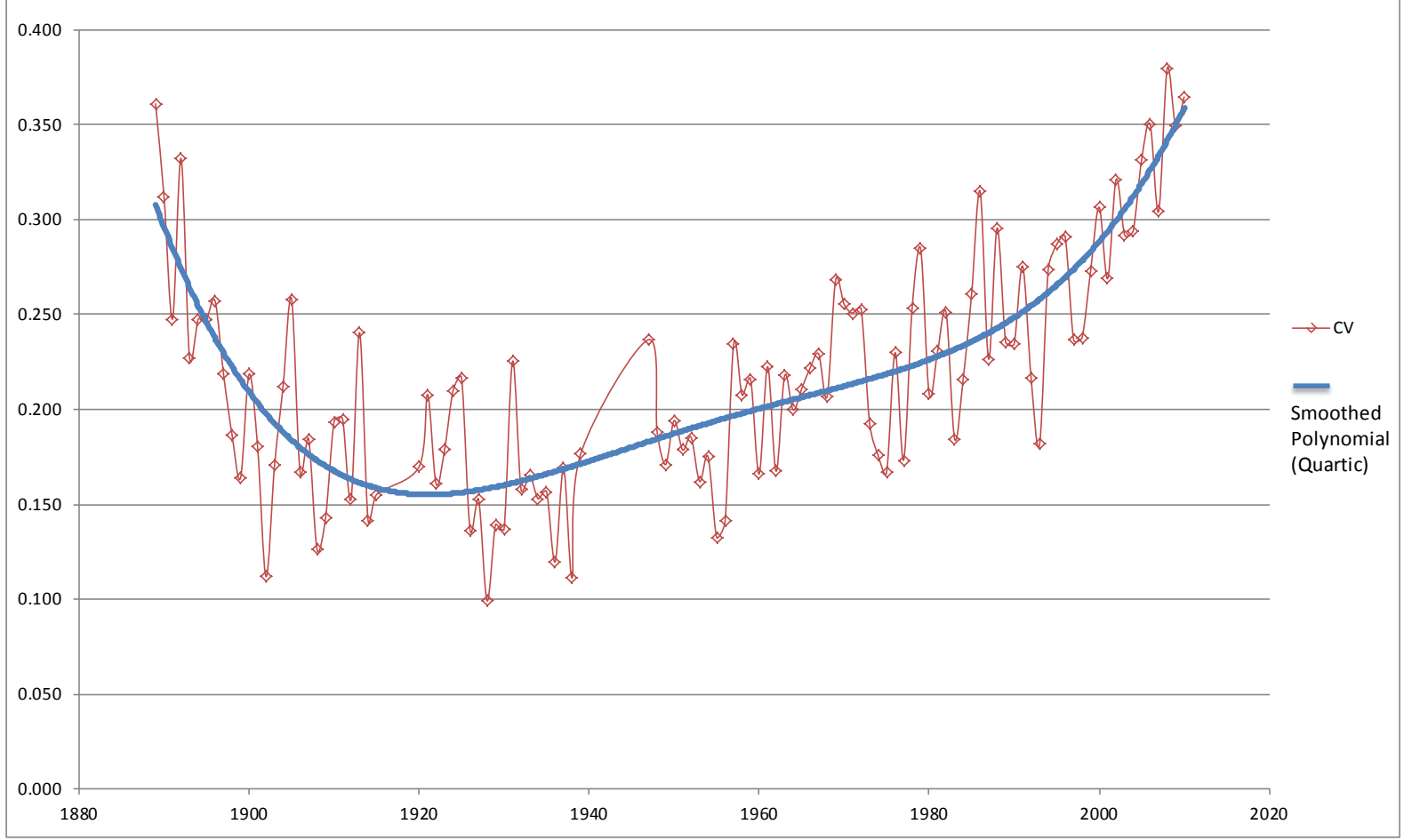

